\title{
Motivasi Nasabah terhadap Pembiayaan Gadai Emas di Bank Syariah Mandiri Cabang Curup
}

\author{
Oleh : Ade Onny Siagian \\ Universitas Bina Sarana Informatika, Email: ade.aoy@bsi.ac.id
}

\begin{abstract}
The research objective is to explain the people's motivation in choosing gold pawn financing at Bank Syariah Mandiri Curup Branch Office. Everyone will love products that comply with Islamic regulations. One of the products or services provided by Bank Syariah Mandiri is pawning. The type of this research is descriptive qualitative with research subjects as staff and bank employees as well as bank customers. Data collection techniques, namely, observation, interviews, documentation and data analysis techniques, data reduction, data presentation and data verification. The results of the customer research have the motivation to choose Bank Syariah Mandiri Curup Branch because it is labeled syari'ah. Gold pawning product consumers have become a fast alternative to making ends meet. Conventional bank financing is different from syari'ah banks. They can feel this with light installments every month. Based on the principles of syari'ah, choosing a gold pawn at Bank Syariah Mandiri Curup is because it has syari'ah principles.
\end{abstract}

Keywords: Motivation, Financing, Gold Pawn

\section{PENDAHULUAN}

Bagi sebagian orang memiliki cara yang efektif untuk menentukan pilihan. Hal tersebut berdasarkan persepsi dan pandangan individu tersebut. Sehingga hal ini menjadi dorongan untuk seseorang memiliki sesuatu berdasarkan dorongan yang didasarkan apa yang mereka pikirkan dan menjadi motivasi dalam menentukan pilihan setiap orang. Pemuasan kebutuhan didorong oleh kekuatan motivasi yaitu motivasi kekurangan (deficiency growth) dan motivasi perkembangan (motivation growth).

Motivasi kekurangan adalah upaya yang dilakukan manusia untuk memenuhi kekurangan yang dialami. Sedangkan motivasi perkembangan adalah motivasi yang tumbuh dari dasar diri manusia untuk mencapai suatu tujuan diri berdasarkan kapasitasnya dalam tumbuh dan berkembang kapasitas atau kemampuan diri masing-masing orang berbeda-beda dan merupakan pembawaan.
Allah SWT telah berfirman dalam Quran Surat Al - Baqarah ayat 283 :

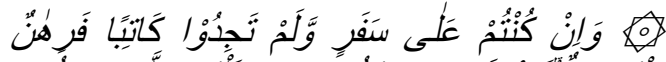

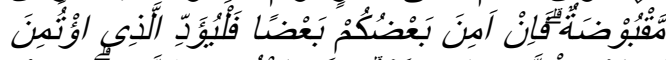

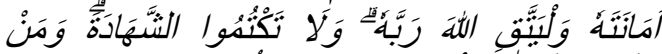

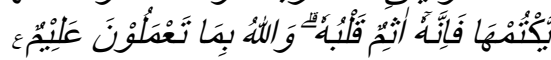

283. Jika kamu dalam perjalanan (dan bermu'amalah tidak secara tunai) sedang kamu tidak memperoleh seorang penulis, Maka hendaklah ada barang tanggungan yang dipegang(oleh yang berpiutang). Akan tetapi jika sebagian kamu mempercayai sebagian yang lain, Maka hendaklah yang dipercayai itu menunaikan amanatnya (hutangnya) dan hendaklah ia bertakwa kepada Allah Tuhannya; dan janganlah kamu (para saksi) Menyembunyikan persaksian. Dan Barang siapa yang menyembunyikannya, Maka Sesungguhnya ia adalah orang yang berdosa hatinya; dan Allah Maha mengetahui apa yang kamu kerjakan

Semua orang akan menyukai produk yang dikeluarkan berdasarkan ketentuan- 
ketentuan Islam. Salah satu produk atau jasa yang disediakan oleh bank syariah mandiri, yaitu gadai adalah menahan salah satu harta milik yang meminjam sebagai pinjaman atas pinjaman yang diterimanya, tanpa kehilangan barang-barang berharga, maka masyarakat dapat menjaminkan barang-barang kelembagaan itu.

Kegiatan penjaminan barang-barang berharga untuk memperoleh sejumlah uang dan dapat ditebus kembali setelah jangka waktu tertentu. Secara sederhana dapat dijelaskan bahwa gadai adalah semacam jaminan utang. ${ }^{1}$ Jadi, dalam kegiatan gadai tersebut bisa diartikan sebagai jaminan sebuah pinjaman atau angunan atas pinjaman yang di manfaatkan oleh nasabah Gadai adalah menahan salah satu harta si peminjam sebagai pinjaman yang diterimanya. Hadirnya gadai emas di Bank Syariah Mandiri tentunya menjadi salah satu competitor. Perusahan gadai yang lebih dahulu melayani masyarakat yang membutuhkan modal dengan sistem gadai. Bank Syariah Mandiri hadir dengan sistem gadai syariah, yaitu menyalurkan pembiayaan kepada masyarakat yang membutuhkan berdasarkan hukum gadai syariah.Bank Syariah Mandiri menerapkan konsep transaksi (akad), yaitu gadai sebagai prinsip dengan akad sebagai tambahan terhadap produk lain, yaitu bank dapat menahan barang nasabah sebagai Konsekuensi dari akad yang dilakukannya. Pembiayaan Gadai Bank Syariah Mandiri, terdapat dua jenis jasa yaitu Bank Syariah Mandiri Gadai Emas dan Bank Syariah Mandiri Cicilan Emas. Gadai Bank Syariah Mandiri adalah gadai yang aturannya berasal dari prinsip syariah. Gadai Bank Syariah Mandiri menggunakan akad qard dan Rahn dengan Ijarah. Gadai tidak hanya terdapat pada Bank Syariah Mandiri di Kota Curup tidak susah ditemukan lembaga Gadai, mulai dari yang bersifat konvensional maupun bersifat syariah. Penelitian ini akan mengukur kuatnya motivasi nasabah terhadap Pembiayaan gadai emas di Bank Syariah Mandiri, di mana masyarakat memberikan ketertarikan yang besar terhadap gadai emas di Bank Syariah Mandiri dan memiliki ketertarikan yang sedikit terhadap cicilan emas. Selanjutnya, gadai emas pada Bank Syariah Mandiri ini sangat memotivasi nasabah untuk menggadaikan emasnya di Bank Syariah Mandiri peneliti telah melakukan observasi awal yaitu bertanya kepada officer gadai dan peneliti menanyakan kepada officer gadai tersebut apakah ada peningkatan dari tahun ke tahun tentang gadai emas yang ada pada Bank Syariah Mandiri dan karyawannya menjawab peningkatan gadai emas ini dari tahun ketahun sanggat lah meningkat. Dapat dilihat pada tabel berikut ini : 
Tabel 1.

Perkembangan Gadai Emas di Bank Syariah Mandiri pada tahun 2017-2019

\begin{tabular}{|l|l|l|}
\hline No & Tahun & Jumlah Nasabah \\
\hline 1 & 2017 & 30 nasabah \\
\hline 2 & 2018 & 45 nasabah \\
\hline 3 & 2019 & 75 nasabah \\
\hline Sumber : Data jumlah nasabah Gadai Emas di Bank Syariah Mandiri Kantor Cabang Curup
\end{tabular}

Berdasarkan tabel di atas menunjukan bahwa perkembangan dan peningkatan jumlah nasabah sangatlah pesat. Hal ini dapat terlihat melalui banyaknya peningkatan jumlah nasabah disetiap tahunnya. Dari uraian diatas, jelas terlihat banyaknya masyarakat termotivasi terhadap Gadai Emas. ${ }^{2}$ Berdasarkan latar belakang di atas sehingga peneliti termotivasi untuk melakukan penelitian yang membahas seputar "Motivasi Nasabah terhadap Pembiayaan Gadai Emas di Bank Syariah Mandiri Kantor Cabang Curup".

\section{METODE PENELITIAN}

\section{Jenis Penelitian}

Penelitian kualitatif adalah suatu pendekatan yang juga disebut pendekatan investigasi karena biasanya peneliti mengumpulkan data dengan cara bertatap muka langsung dan berinteraksi dengan orang-orang di tempat penelitian dan mendefinisikan metode kualitatif sebagai prosedur penelitian yang menghasilkan data deskriptif berupa kata-kata tertulis atau lisan dari orang-orang atau perilaku yang dapat diamati.

Istilah penelitian kualitatif dimaksudkan sebagai jenis penelitian yang temuan - temuannya tidak diperoleh melalui prosedur statistik atau bentuk hitungan lainnya. Maka dalam kajian ini digunakan jenis data 'Kualitatf'. Kualitatif adalah suatu data yang diperoleh dengan mengkaji dan menggali fenomena dalam lingkungan yang dituju sebagai bahan penelitian dan sumber data secara objektif di lapangan mengenai Motivasi Nasabah terhadap Pembiayaan Gadai Emas di Bank Syariah Mandiri Kantor Cabang Curup.

\section{Data dan Sumber Data}

Sumber data adalah subjek di mana data diperoleh. Sumber data utama dalam Penelitian kualitatif ialah kata-kata atau tindakan selebihnya adalah data tambahan seperti dokumen dan lain-lain.

Dalam penelitian ini, subjeknya adalah nasabah, sedangkan objeknya adalah produk gadai emas. Dari subjek dan objek tersebut, peneliti menggunakan tambahan motivasi nasabah dalam menjadi nasabah Bank Syariah Mandiri Kantor Cabang Curup, hal ini agar peneliti mendapatkan jawaban sesuai dengan latar belakang peneliti. Pengumpulan data yang akan peneliti lakukan menjadi dua macam yaitu:

a. Data Primer

Data primer adalah data yang langsung dikumpulkan oleh peneliti (atau petugas - petugasnya) dari sumber pertama . ${ }^{3}$ Atau data yang dikumpulkan langsung dari individuindividu yang diselidiki (data tangan pertama) dan data primer ini diperoleh langsung dari wawancara yang dilakukan kepada ketertarikan dan yaitu masyarakat kota Curup.

b. Data Sekunder 
Data sekunder biasanya telah tersusun dalam bentuk dokumendokumen, misalnya data mengenai keadaan demografis suatu daerah. Data sekunder yang diperoleh peneliti adalah data yang diperoleh langsung dari pihak-pihak yang berkaitan berupa data - data dari masyarakat Kota Curup terhadap gadai emas dan berbagai literatur yang relevan dengan pembahasan.

\section{Subjek Penelitian}

Subjek penelitian adalah beberapa karyawan dan staf Bank Syariah Mandiri dan nasabah. Teknik pemilihan informan yang digunakan adalah teknik sampling bola salju (snow ball sampling), yang merupakan teknik penarikan sampel, yang diawali dengan penentuan sampel pertama, sampel berikutnya ditentukan berdasarkan informasi sampel pertama, dan demikian seterusnya. Berapa besar sampel ideal sepenuhnya ditentukan oleh peneliti sampai menganggap bahwa jumlah sampel itu dipandang memadai. adapun jumlah subjek dalam penelitian ini ialah berjumlah 6 orang. Namun apabila ada data yang belum jelas atau membutuhkan kejelasan yang lebih rinci dan akurat, maka peneliti akan mengulang kembali untuk memperoleh kejelasan informasi yang didapat. Maka dalam penelitian ini tidak akan ditentukan banyaknya jumlah sampel yang terlibat, akan tetapi banyaknya sampel akan ditentukan oleh tingkat kebutuhan dalam perolehan data dan kedalaman data yang diperoleh, oleh sebab itu informan yang akan dipilih diharapkan informan yang benar-benar dianggap mampu untuk menggambarkan tentang analisis manajemen kredit pada Bank Syariah Mandiri.

\section{Teknik Pengumpulan Data}

a. Wawancara yaitu percakapan dengan maksud tertentu. Percakapan itu dilakukan oleh dua pihak, yaitu pewawancara yang mengajukan pertanyaan dan terwawancara yang memberikan jawaban atas pertanyaan itu. Penulis melakukan tanya jawab dengan mengajukan beberapa pertanyaan berlangsung kepada ketertarikan dan gadai emas Bank Syariah Mandiri.

b. Observasi pada tahap ini peneliti melakukan orientasi mengenai gambaran umum tentang mencakup detail secara umum bagaimana masyarakat Rejang Lebong dalam memahami gadai emas di Bank Syariah serta motivasi masyarakat Rejang Lebong terhadap gadai emas Bank Syariah serta mengadakan sosialisasi gadai emas di Rejang Lebong tujuannya mempermudah mendapatkan informasi - informasi yang akan dikaji oleh peneliti

c. Dokumentasi yaitu teknik yang digunakan untuk mengumpulkan data berupa data - data tertulis yang mengadung keterangan dan penjelasan.

\section{Analisa Data}

Analisa data adalah proses yang merinci usaha secara formal untuk menemukan tema dan merumuskan ide seperti yang disarankan oleh data dan sebagai usaha untuk memberikan bantuan pada tema dan ide itu. Teknik analisa data dalam kasus ini menggunakan analisa data kualitatif mengikuti konsep yang diberikan Miles dan Huberman, yang mana mereka mengemukakan bahwa aktivitas dalam analisa data kualitatif dilakukan secara interaktif dan berlangsung secara terus menerus pada setiap tahapan penelitian sampai tuntas, sehingga datanya sudah jenuh. Penelitian ini akan menggunakan teknik analisis data kualitatif dengan menggunakan tiga metode analisis, yaitu :

a. Reduksi data.

Reduksi data diartikan sebagai proses pemilihan data yang diperoleh peneliti yang diperoleh dari hasil observasi dan wawancara. Pada tahap ini peneliti memberikan kode atau 
menandai data - data penting yang diperlukan.

b. Penyajian data

Penyajian data dibatasi sebagai kumpulan informasi tersusun yang memberi kemungkinan adanya penarikan kesimpulan dan pengambilan tindakan. Dengan penyajian tersebut peneliti memaparkan data yang diperoleh dari hasil wawancara dan observasi sesuai dengan rumusan masalah yang ditentukan.

c. Conclusion (penarikan kesimpulan)

Penarikan kesimpulan hanyalah sebagian dari suatu kegiatan konfigurasi yang utuh. Kesimpulan juga di Verifikasi selama penelitian berlangsung. Verifikasi itu mungkin sesingkat pemikiran kembali yang melintas dalam penganalisisan selama peneliti menulis. ${ }^{4}$ Suatu tinjauan ulang pada catatan - catatan lapangan atau mungkin menjadi begitu seksama dan makan tenaga dengan peninjauan kembali serta tukar pikiran di antara teman sejawat untuk mengembangkan 'intersubjektif' atau temuan pada salinan dan data yang lain. Singkatnya makna-makna yang muncul dari data harus diuji kebenarannya, kecocokannya, yakni yang merupakan validitasnya.

\section{PEMBAHASAN}

\section{Motivasi Nasabah dalam Memilih Produk Gadai Emas di Bank Syari'ah Mandiri Kantor Cabang Curup}

Masyarakat memiliki motivasi terhadap gadai emas di Bank Syari'ah Mandiri Kantor Cabang Curup. Dalam penelitian ini peneliti ingin melihat bagaimana ketertarikan masyarakat terhadap gadai emas itu sendiri.
Sebagaimana dijelaskan berdasarkan hasil wawancara di bawah ini:

Berdasarkan hasil dengan pihak Bank Syariah Mandiri bahwa "Melihat ketertarikan masyarakat saat ini, banyak sebagian mereka memilih gadai emas saat mereka memerlukan keperluan atau biaya hidup. Hal ini bisa dilihat dengan bertambahnya nasabah. Apa lagi di saat pandemi saat ini membuat pihak Bank mengalami lonjakan jumlah nasabah. Memang sebenarnya tujuan kita untuk membantu perekonomian dan usaha masyarakat terutama para nasabah kita". Dan biaya titip yang kita tawarkan pun relatif ringan.

Hasil Wawancara Di Atas Diketahui Berdasarkan Informasi Pihak Bank Syariah Mandiri bahwa masyarakat memiliki ketertarikan yang baik terhadap gadai emas tersebut. hal ini dibuktikan dengan bertambahnya jumlah nasabah apalagi di saat sekarang ini. Gadai ini bertujuan untuk mengatasi agar masyarakat yang sedang membutuhkan uang tidak jatuh ke tangan para pelepas uang atau rentenir yang bunganya relatif tinggi. Perusahaan gadai menyediakan pinjaman uang dengan jaminan barang-barang berharga. Meminjam uang ke perusahaan gadai bukan saja karena prosedurnya yang mudah dan cepat, tetapi karena biaya yang dibebankan lebih ringan jika dibandingkan dengan para pelepas uang atau tukang ijon. Akan tetapi, kendala utamanya adalah prosedurnya yang rumit dan memakan waktu yang relatif lebih lama. Kemudian di samping itu, persyaratan yang lebih sulit untuk dipenuhi seperti dokumen yang harus lengkap, membuat masyarakat mengalami kesulitan untuk memenuhinya. Begitu pula dengan jaminan yang diberikan harus barang-barang tertentu, karena tidak semua barang dapat dijadikan jaminan di bank. Selain itu berdasarkan pengalaman para sahabat saya yang juga merupakan nasabah bank tersebut juga menilai gadai ini sangat menguntungkan 
kita dikarenakan biaya taksiran emas disana sangat tinggi dan biaya titipnya relative murah " "saya memang tertarik menggadaikan emas yang mempercayai Bank berlabelkan syari'ah bisa menjamin aset. Jadi saya tidak perlu kawatir dengan aset saya yang saya jadikan agunan. ""Saya memyakini bahwa ia memiliki kekuatan hukum dan keamanan yang tepat. Yang pertama masyarakat menyambut antusias gadai emas Di Bank Syariah Mandiri Karena Menilai Lembaga Ini Lebih Aman Sebagai Penitipan Aset Atau Agunan Para Nasabahnya.

"Kami memilih gadai emas karena ia merupakan aset yang berharga dan mudah untuk dijual atau gadai." Karena aset emas yang kita miliki di rumah jadi kita pilih emas saja, karena proses gadainya tidak.

\section{"Saya memilih produk emas ini karena dinilai lebih praktis dari pada gadai yang lainnya"}

Para nasabah memiliki alasan mengapa mereka menggadaikan emas atau produk gadai emas di Bank Syariah Mandiri. Hal ini disebabkan bahwa emas ini merupakan aset yang mudah dimiliki sebagian nasabah karena tidak terlalu besar seperti aset bangunan atau tanah. Yang intinya mereka memilih emas sebagai aset sekaligus aksesori mereka untuk tampil lebih meriah dan percaya diri. Proses gadai nya tidak banyak memerlukan persyaratan. Para nasabah keuntungan yang didapatkan sebagai konsumen dengan melakukan pembiayaan melalui produk gadai emas di Bank Syariah Mandiri. "'Ya saya memilih Bank Syariah Mandiri karena memiliki beberapa keuntungan. dan mereka tidak merasa berat atau terbeban dengan pembiayaan tersebut. serta pihak Bank Syariah Mandiri Selalu Memberikan Pengertian Dan Arahan Apa Bila nasabah mereka mengalami kredit macet dan tidak langsung menyita aset mereka

Suatu tindakan individu yang diarahkan kepada benda mati tidak masuk dalam kategori tindakan sosial. Gadai adalah
Penahan sesuatu barang sebagai tanggungan utang, atau menjadikan sesuatu benda bernilai menurut pandangan Syara' sebagai tanggungan marhun Bih, sehingga dengan adanya tanggungan utang itu seluruh atau sebagian utang dapat diterima. Lembaga Keuangan Syari'ah adalah badan usaha yang kegiatannya di bidang keuangan yang didasarkan prinsip-prinsip syari'ah atau dengan kata lain bersumber dari ayat-ayat $\mathrm{Al}$ Quran dan As - Sunnah yang berkaitan dengan etika bermua'malah dan transaksi ekonomi, baik dalam bentuk bank maupun non bank. Para nasabah memiliki motivasi untuk memilih Bank Syariah Mandiri ini karena berlabelkan syari'ah.

\section{" Berbeda jumlah biaya titipnya lebih kecil dibandingkan dengan yang lainnya"}

Peneliti menyimpulkan bahwa nasabah berasumsi bahwa Pembiayaan pada bank konvensional berbeda dengan bank syari'ah. Motivasi lain nasabah dalam memilih gadai emas di Bank Syariah Mandiri Curup ini ialah karena memiliki prinsip syari'ah.

\section{"Prosedur pembiayaan sesuai dengan aturan agama atau syari'ah"}

Gadai syari'ah adalah disiplin bisnis strategis yang mengarahkan proses menciptakan, menawarkan, dan mengubah nilai seorang pemrakarsa kepada para pemangku kepentingan, yang dalam keseluruhan prosesnya sesuai dengan perjanjian dan prinsip muamalah dalam Islam. Ini berarti bahwa dalam gadai Islam, seluruh proses proses penciptaan, proses penawaran, dan proses perubahan nilai mungkin tidak memiliki halhal yang bertentangan dengan kontrak dan prinsip-prinsip muamalah Islam. Gadai syari'ah bukanlah konsep yang eksklusif, fanatik, anti modernitas, dan kaku. Gadai syari'ah adalah konsep gadai yang fleksibel, seperti luasnya dan fleksibilitas syari'ah Islam yang melandasinya. gadai syari'ah adalah gadai profesional dengan 
penampilan bersih, rapi, dan bersahaja, apa pun gaya atau gaya pakaian yang mereka kenakan. Salah satu ciri gadai syari'ah yang tidak dimiliki dalam gadai konvensional yang selama ini dikenal adalah sifat keagamaannya . Kondisi ini tercipta dari kesadaran akan nilai-nilai agama, yang dianggap penting dan mewarnai kegiatan gadai agar tidak jatuh ke tindakan yang dapat merugikan orang lain. Jiwa seorang penggadaian syari'ah percaya bahwa hukum Syari'ah yang teisme atau ilahi ini adalah yang paling adil, paling sempurna, paling selaras dengan semua bentuk kebaikan, paling mampu mencegah semua bentuk kerusakan, paling mampu mewujudkan kebenaran, menghancurkan kejahatan, dan menyebarkan kesejahteraan. Dengan demikian, gadai syari'ah adalah konsep gadai yang mengutamakan nilai-nilai moral dan etis, apa pun agamanya. Karena nilai-nilai moral dan etika adalah nilai-nilai universal, yang diajarkan oleh semua agama d. Informasi merupakan hal penting dalam memilih suatu produk yang akan kita ambil. Secara singkat, mencari informasi produk adalah usaha dalam mencari tahu suatu produk dengan melihat beberapa aspek sebagai indikator yang harus ada pada suatu produk. Sehingga apabila produk tersebut tidak memenuhi indikator - indikator yang ada,. Kita bisa bertanya pada teman yang pernah atau yang sudah menjadi nasabah. Ya saya mendapatkan informasi dari brosur yang dibagikan oleh pegawainya dan akhirnya saya tertarik.

Hasil penelitian menunjukan bahwa ada beberapa ketertarikan masyarakat terhadap gadai di Bank Syariah Mandiri masyarakat memiliki ketertarikan yang baik terhadap gadai emas tersebut. Yang pertama masyarakat menyambut antusias gadai emas di Bank Syariah Mandiri karena menilai lembaga ini lebih aman sebagai penitipan aset atau anggunan para nasabahnya. Para nasabah memiliki alasan mengapa memilih produk gadai emas. Seperti menggadaikan emas atau produk gadai emas di Bank Syariah Mandiri karena mudah dimiliki sebagian nasabah karena tidak terlalu besar. Secara umum tanggapan dapat diartikan sebagai hasil atau kesan yang didapat dari pengamatan. Berdasarkan temuan penelitian dengan teori yang ada bahwa nasabah Bank Syariah Mandiri memiliki tangapan atau ketertarikan terhadap gadai emas. Sebagaimana berdasarkan temuan bahwa semua ketertarikan yang diberikan oleh nasabah ialah berupa ketertarikan positif. Kedua, konsumen produk gadai emas menjadi alternatif cepat mencukupi kebutuhan hidup. Keempat, Prinsip syari'ah adalah dalam memilih gadai emas di Bank Syariah Mandiri Curup ini ialah karena memiliki prinsip syari'ah. Kelima, Informasi merupakan hal penting dalam memilih suatu produk informasi dari sumber atau nasabah bahwa informasi merupakan salah satu yang menjadi motivasi mereka dalam memilih pembiayaan di gadai Bank Syariah Mandiri. Misalnya dengan mendapatkan brosur yang dibagikan pihak gadai sebagai ajang promosi suatu produk. Wirawan, ada beberapa yang memotivasi sesorang untuk memilih atau menggunakan suatu produk. Tindakan ini merupakan suatu tindakan sosial yang dilakukan seseorang didasarkan atas pertimbangan dan pilihan sadar yang berhubungan dengan tujuan tindakan itu. Tindakan rasional nilai memiliki sifat bahwa alat-alat yang ada hanya merupakan pertimbangan dan perhitungan yang sadar, sementara tujuan - tujuannya sudah ada didalam hubungannya dengan nilai-nilai individu yang bersifat absolut. Tindakan yang dilakukan berdasarkan pertimbangan nilai etika, adat maupun nilai lainnya. Keempat, Tindakan tradisional Tindakan ini, seseorang memperlihatkan perilaku tertentu karena kebiasaan yang diperoleh dari diri sendiri maupun orang lain, tanpa refleksi yang sadar atau perencanaan yang matang. 
Berdasarkan temuan penelitian yang ada penulis menyimpulkan bahwa ada beberapa yang memotivasi sesorang untuk memilih atau menggunakan suatu produk. Tujuan tersebut didasarkan berdasarkan informasi dan label syari'ah yang menjadi tolak ukur mereka dalam meimilih Bank Syariah Mandiri. Nasabah memiliki pertimbangan dan perhitungan yang sadar, sementara tujuan tujuannya sudah ada didalam hubungannya dengan nilai-nilai individu yang bersifat mutlak. Ada pula nasabah yang memilih Bank Syariah Mandiri karena Tindakan afektif sifatnya spontan, kurang rasional, dan merupakan ekspresi emosional dari individu.

\section{KESIMPULAN}

Nasabah memilih produk pasti memiliki motivasi tersendiri. Ada beberapa yang memotivasi nasabah diantaranya: Pertama, nasabah memiliki motivasi untuk memilih Bank Syariah Mandiri ini karena berlabelkan syari'ah.

Kedua, konsumen produk gadai emas menjadi alternatif cepat mencukupi kebutuhan hidup dan untuk memenuhi kepuasan mental dan fisik demi kelangsungan hidup sehari-hari.

Ketiga, pembiayaan pada bank konvensional berbeda dengan bank syari'ah. Hal ini bisa mereka rasakan dengan ringannya angsuran mereka pada tiap bulannya atau setiap mengangsur kredit.

Keempat, Prinsip syari'ah adalah dalam memilih gadai emas di Bank Syariah Mandiri ini ialah karena memiliki prinsip syari'ah.

Kelima, Informasi merupakan hal penting dalam memilih suatu produk informasi dari sumber atau nasabah bahwa informasi merupakan salah satu yang menjadi motivasi mereka dalam memilih pembiayaan di gadai Bank Syariah Mandiri. Informasi tersebut didapatkan dengan berbagai cara. Misalnya dengan mendapatkan brosur yang dibagikan pihak gadai sebagai ajang promosi suatu produk.

\section{SARAN}

Pihak bank harus lebih selektif dalam mendeteksi dan pengenalan diri calon nasabah akan sangat penting untuk mengantisipasi kemungkinan masalah yang timbul, baik secara individual maupun secara portofolio bagi hasil dan menyusun rencana serta mengambil langkah sebelum masalah kredit bermasalah benar terjadi.

Perlu dibentuk undang-undang khusus tentang penanggulangan kredit bermasalah baik dari segi hukum substantif. dan nasabah harus turut menaati peraturan dalam menjalankan kredit dan harus tepat waktu. Sehingga dengan demikian mampu mendukung program - program yang produktif yang disediakan oleh bank.

\section{DAFTAR PUSTAKA}

Abdul Manan. (2012). Hukum Ekonomi Syariah. Jakarta: Kencana.

Abraham H.Maslow.( 1984). Motivasi dan Keperibadia. Jakarta:Gramedia.

Abu Ahmadi. (1992). Psikologi Belajar. Jakarta: Rineka Cipta, Cet. Ke-3

Ade Sofyan Mulazid. (2012) Kedudukan Pegadaian Syariah Dalam Sistem Hukum Nasional di Indonesia.Jakarta: Kementrian Agama RI.

Adiwarman A. Karim. (2013) Bank Islam Analisis Fiqih dan Keuangan. Jakarta: PT Raja Grafindo Persada.

Adrian Sutedi. (2011) Hukum Gadai Syariah. Bandung: Alfabeta. Agung Herlambang. Sejarah Bank Syariah Mandiri. Bank Syariah Mandiri Kc Jakarta : 2000

Ahmad Subandi. (1982). Psikologi Sosial Jakarta: Bulan Bintang, Cet. Ke-11

Ahmad Syakir. Syaikh. (2014). Mukhtashar Tafsir Ibnu Katsir. Jakarta: Darus Sunnah Press, Jilid 1. Cet. 2

Anang Firmasyah dan Budi. (2015) Pengantar Manajemen. Yogyakarta: $\mathrm{Cv}$ Budi Utama. cet 3

Andrian Sutedi. (2011) Hukum Gadai Syariah. Bandung: Alfabeta. 
Ernawati. (2017) Implikasi Gadai Emas IB Barokah Terhadap Profitabilitas Bank Jatim Cabang Syariah Sidoarjo.'Skripsi.Fak. Ekonomi UIN Sunan Ampel, Syariah surabaya,

Evan. (2005) Nilai-Nilai Perusahaan Bank Syariah Mandiri. Bank Syariah Mandiri KC Curup.

Eko Fitri Nuryanto, (2017) Analisis Pengaruh Fluktuasi Harga Emas, Tingkat Inflasi Dan Ukuran Perusahaan Terhadap Produk Gadai Emas Pada Bank Umum Syariah Periode 2012-2016." Skripsi. Fak. Ekonomi Universitas. Muhammadyah Yogyakarta.

Kusuma. Mahasiswa "Analisis Faktor-Faktor yang Mempengaruhi Tingkat Pengembalian Pembiayaan Studi Kasus pada KJKS Perambabulan AlQomariyah Kabupaten Cirebon” Institut Agama Islam Negeri IAIN MEPI

MULYONO, H., HADIAN, A., PURBA, N., \& PRAMONO, R. (2020). Effect of Service Quality Toward Student Satisfaction and Loyalty in Higher Education. The Journal of Asian Finance, Economics and Business (JAFEB), 7(10), 929-938.

Sharma, D., Taggar, R., Bindra, S., \& Dhir, S. (2020). A systematic review of responsiveness to develop future research agenda: a TCCM and bibliometric analysis. Benchmarking: An International Journal.

Sunandar. (2005) Nilai-Nilai Perusahaan Bank Syariah Mandiri Bank Syariah Mandiri KC Curup.

Sunandar. (2005) Sejarah Bank Syariah Mandiri Bank Syariah Mandiri KC CURUP.

Thorik Gunara \& Utus Hardiono Sudibyo. (2007) Marketing Perbankan Jawa Barat: Madani Prima.

Tim Penyusun Kamus Pusat Pembinaan dan Pengembangan Bahasa, 1988 Kamus Besar Bahasa Indonesia Jakarta: Balai Pustaka.
Tuturtika. Proposal Penelitian”. Tuturtika.blogspot.com di Akses pada Tanggal 31 Januari 2020 Pada Pukul 12.40

Veitzal Rifa'i, Andria Permata Veitza dan Ferry N. Indroes, (2007) Bank dan Financial Institution Management. Jakarta: Raja Grafindo Persada,

Zainal Mutaqin. (2010) "Faktor-faktor penyebab pembiayaan bermasalah pada pembiayaan murabahah studi kasus pada BMT Al-Falah Sindanglaut Cirebon Skripsi.

Zainudin Ali, (2008) Hukum Gadai Syariah. Jakarta: Sinar Grafika.

Zainul Arifin. (2009) Dasar-Dasar Manajemen Bank Syariah. Jakarta: Pustaka Alvaber Anggota IKAPI.

Www.syariahmandiri.co.id/en/category/infoperusahaan/profil-perusahaan/. Diakses tanggal 12019 pada pukul 20.30 WIB 